\title{
Liquid Chromatographic Method for the Quantification of Antipsychotic Agent Iloperidone in Pharmaceutical Formulation
}

\author{
Usmangani K. Chhalotiya, ${ }^{1}$ Kashyap K. Bhatt, ${ }^{1}$ Dimal A. Shah, ${ }^{1}$ and Jigar R. Patel ${ }^{2}$ \\ ${ }^{1}$ Indukaka Ipcowala College of Pharmacy, Beyond GIDC Phase V, Vithal Udyognagar, New Vallabh Vidyanagar, \\ Gujarat, Anand 388121, India \\ ${ }^{2}$ Sun Pharmaceutical Industries Ltd, Formulation and Development Department, Baroda 390020, \\ Gujarat, India \\ Correspondence should be addressed to Usmangani K. Chhalotiya, usmangani84@gmail.com
}

Received 14 December 2011; Accepted 9 January 2012

Academic Editor: T. Macko

Copyright (C) 2012 Usmangani K. Chhalotiya et al. This is an open access article distributed under the Creative Commons Attribution License, which permits unrestricted use, distribution, and reproduction in any medium, provided the original work is properly cited.

\begin{abstract}
Liquid chromatographic method for the quantitative determination of iloperidone in the pharmaceutical dosage form was developed. A reversed phase column with mobile phase containing $0.02 \mathrm{M}$ potassium dihydrogen phosphate: methanol: acetonitrile $\left(55: 25: 20, \mathrm{v} / \mathrm{v} / \mathrm{v}, \mathrm{pH} 4\right.$ adjusted with phosphoric acid) was used. The flow rate was $1.0 \mathrm{~mL} \mathrm{~min}^{-1}$, and effluents were monitored at $230 \mathrm{~nm}$. The retention time of iloperidone was $11.6 \mathrm{~min}$. Iloperidone stock solutions were subjected to acid and alkali hydrolysis, chemical oxidation, and dry heat degradation. The degraded product peaks were well resolved from the pure drug peak with significant difference in their retention time values. Stressed samples were assayed using developed LC method. The proposed method was validated with respect to linearity, accuracy, precision, and robustness. The method was successfully applied to the estimation of iloperidone in tablet dosage forms.
\end{abstract}

\section{Introduction}

Iloperidone (1-[4-[3-[4-(6-fluoro-1,2-benzisoxazol-3-yl)-1piperidinyl]propoxy]-3-methoxy phenyl]ethanone) (Figure 1) is a second-generation atypical antipsychotic agent recently approved by The United States Food and Drug Administration and is indicated for the acute treatment of schizophrenia in adults. Iloperidone is a white to offwhite finely crystalline powder. It is practically insoluble in water, very slightly soluble in $0.1 \mathrm{~N} \mathrm{HCl}$, and freely soluble in chloroform, ethanol, methanol, and acetonitrile. It is commercially available in the form of oral tablets in seven different strengths, namely, $1 \mathrm{mg}, 2 \mathrm{mg}, 4 \mathrm{mg}, 6 \mathrm{mg}, 8 \mathrm{mg}$, $10 \mathrm{mg}$, and $12 \mathrm{mg}$. [1,2].

In the literature, a liquid chromatographic-mass spectrometric (LC-MS) method has been described by Mutlib et al. to quantitate iloperidone, and its principal metabolite, 4-[3[4-(6-fluoro-1,2-benzisoxazol-3-yl)-l-piperidinyl]propoxy]3 -methoxy- $\alpha$-methylbenzenemethanol, in human plasma [3]. Sainati et al. have reported preliminary pharmacokinetic assessment by HPLC method with ultraviolet detection to support human pharmacokinetic studies based upon a 3 and $5 \mathrm{mg}$ dosage regimen [4]. Mutlib et al. have reported that HPLC-NMR and HPLC-NMR-MS methods have been developed for identification of in vivo and in vitro metabolites of iloperidone [5].

Literature survey reveals that a stability indicating analytical method for determination of iloperidone in dosage forms has been published [6]. The objective of this study was to develop a new, simple, rapid, precise, accurate, and specific stability-indicating HPLC method through stress studies as per ICH-recommended stress conditions [7-11].

\section{Experimental}

2.1. Apparatus. The liquid chromatographic system of company PerkinElmer Life and Analytical Sciences, (Shelton, USA) series 200 containing quaternary gradient pump, variable wavelength programmable $\mathrm{UV} / \mathrm{V}$ is detector, and rheodyne injector with $20 \mu \mathrm{L}$ fixed loop were used. A $\mathrm{C}_{18}$ 


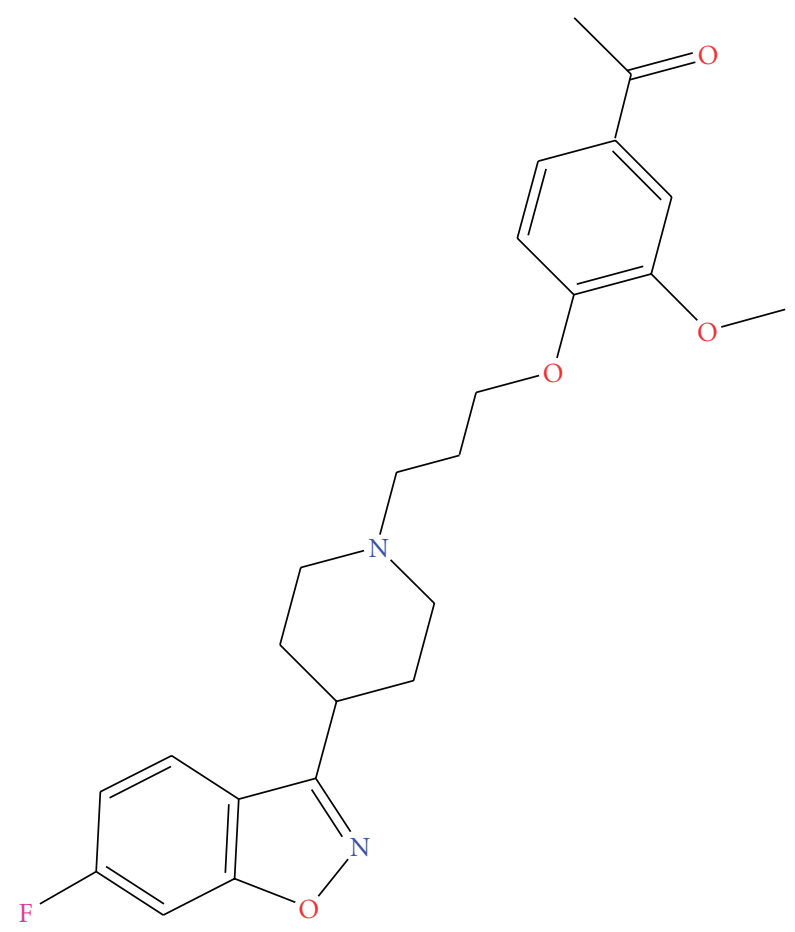

FIgure 1: Chemical structure of iloperidone.

column (Brownlee Analytical, Shelton, USA) with $250 \times$ $4.6 \mathrm{~mm}$ i.d. and $5 \mu \mathrm{m}$ particle size was used as a stationary phase.

2.2. Reagents and Materials. Analytically pure ILO was procured as gift sample from Sun Pharmaceutical Pvt. Ltd., (Baroda, India). Methanol and water (E. Merck, Mumbai, India) were of LC grade, while potassium dihydrogen phosphate and orthophosphoric acid (S.D. Fine Chemicals, Mumbai, India) were of analytical grade and used for the preparation of mobile phase. Tablet formulation A (Ilosure (4 mg), Sun pharmaceuticals Ltd., Ahemadabad, India) containing labeled amount of $4 \mathrm{mg}$ of iloperidone was purchased from local market.

\subsection{Preparation of Mobile Phase and Stock Solution. Mobile} phase was prepared by accurately weighing $0.340 \mathrm{~g}$ of potassium dihydrogen phosphate and dissolving in $100 \mathrm{~mL}$ of water. $55 \mathrm{~mL}$ of buffer was mixed with $25 \mathrm{~mL}$ of methanol and $20 \mathrm{~mL}$ of acetonitrile, and $\mathrm{pH}$ was adjusted to $\mathrm{pH} 4$ using orthophosphoric acid (OPA). The solution was filtered with Whatman filter paper no. $42(0.45 \mu \mathrm{m})$. The solution was sonicated for $15 \mathrm{~min}$ for degassing prior to use.

Stock solutions were prepared by accurately weighing $10 \mathrm{mg}$ of ILO and transferring to $10 \mathrm{~mL}$ volumetric flasks containing $3 \mathrm{~mL}$ of acetonitrile. The flasks were sonicated for 10 minutes to dissolve the solids. Volumes were made up to the mark with acetonitrile, which gave $1000 \mu \mathrm{g} / \mathrm{mL}$. Aliquots from the stock solutions were appropriately diluted with mobile phase to obtain working standards of $100 \mu \mathrm{g} / \mathrm{mL}$ of drug.
2.4. Chromatographic Conditions. A reversed-phase $\mathrm{C}_{18}$ column (Brownlee) equilibrated with mobile phase comprising of $0.025 \mathrm{M}$ potassium dihydrogen phosphate: methanol: acetonitrile $(55: 25: 20, \mathrm{pH} 4)$ was used. Mobile phase flow rate was maintained at $1 \mathrm{~mL} / \mathrm{min}$, and effluent was monitored at $230 \mathrm{~nm}$. A $20 \mu \mathrm{L}$ of sample was injected using a fixed loop, and the total run time was $15 \mathrm{~min}$. All the chromatographic separations were carried out at controlled room temperature $\left(25 \pm 2^{\circ} \mathrm{C}\right)$.

2.5. Calibration Curves for ILO. Appropriate aliquots of ILO working standard solution were taken in different $10 \mathrm{~mL}$ volumetric flasks. The volume was made up to the mark with mobile phase to obtain final concentrations of $0.1,0.5,1,5,10$, and $20 \mu \mathrm{g} / \mathrm{mL}$ of ILO, respectively. The solutions were injected using a $20 \mu \mathrm{L}$ fixed loop system, and chromatograms were recorded. Calibration curves were constructed by plotting peak area versus concentrations of the drug, and regression equations were computed for ILO.

2.6. Analysis of Marketed Formulations. Twenty tablets were weighed accurately and finely powdered. Tablet powder equivalent to $4 \mathrm{mg}$ ILO was taken in $10 \mathrm{~mL}$ volumetric flask. A few $\mathrm{mL}$ of acetonitrile was added to the above flask, and the flask was sonicated for 15 minutes. The solution was filtered in another $10 \mathrm{~mL}$ volumetric flask using Whatman filter paper no. 42 , and volume was made up to the mark with the same solvent.

Appropriate volume of the aliquot was transferred to a $10 \mathrm{~mL}$ volumetric flask, and the volume was made up to the mark with the mobile phase to obtain a solution containing $4 \mu \mathrm{g} / \mathrm{mL}$ of ILO. The solution was sonicated for $10 \mathrm{~min}$. It was injected as per the above chromatographic conditions, and peak area was recorded. The quantifications were carried out by keeping these values to the linear equation of calibration curve.

2.7. Validation. The method was validated for accuracy, precision, specificity, detection limit, quantitation limit, and robustness.

2.7.1. Accuracy. The accuracy of the method was determined by calculating recoveries of ILO by method of standard additions. Known amount of ILO $(0,2,4$, and $6 \mu \mathrm{g} / \mathrm{mL})$ was added to a prequantified sample solutions, and the amount of ILO was estimated by measuring the peak area and by fitting these values to the straight-line equation of calibration curve.

2.7.2. Precision. Repeatability study was performed by injecting the solution containing ILO $(5 \mu \mathrm{g} / \mathrm{mL})$ six times repeatedly, and peak area was measured. The results are reported in terms of relative standard deviation. The intraday and interday precision study of ILO was carried out by estimating the corresponding responses 3 times on the same day and on 3 different days (first, second, and third day) for 3 different concentrations of ILO $(0.1,1$, and $20 \mu \mathrm{g} / \mathrm{mL})$, and the results are reported in terms of relative standard deviation (RSD). 


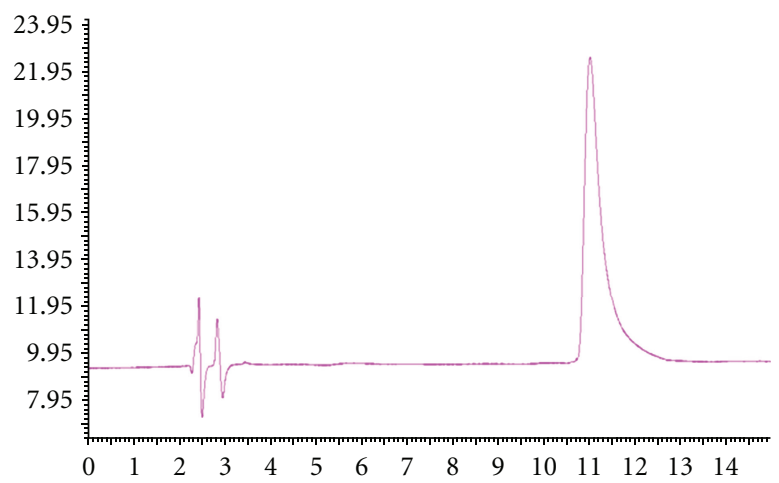

(a)

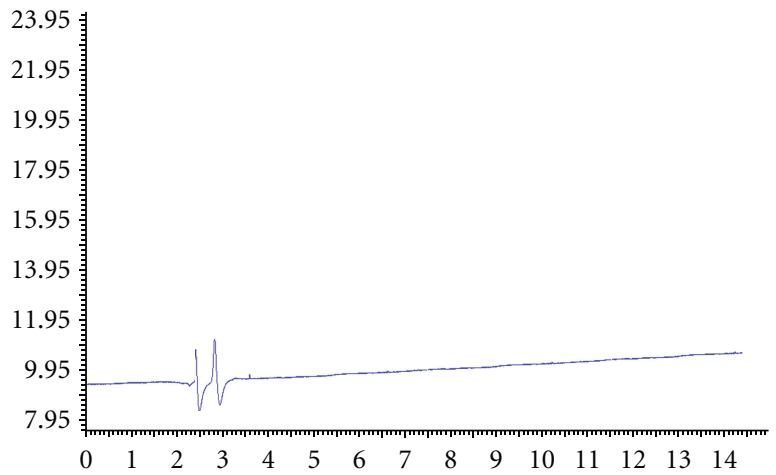

(b)

Figure 2: (a) Liquid chromatogram of ILO. (b) Liquid chromatogram of placebo.

2.7.3. Specificity. The specificity was estimated by spiking commonly used excipients (starch, talc, and magnesium stearate) into a preweighed quantity of drug. The chromatogram was taken by appropriate dilutions, and the quantities of drugs were determined.

2.7.4. Limit of Detection and Quantification. The detection limit is defined as the lowest concentration of an analyte that can reliably be differentiated from background levels. Limit of quantification of an individual analytical procedure is the lowest amount of analyte that can be quantitatively determined with suitable precision and accuracy. LOD and LOQ were calculated using the following equation as per ICH guidelines: $\mathrm{LOD}=3.3 \times \sigma / S$ and $\mathrm{LOQ}=10 \times \sigma / S$, where $\sigma$ is the standard deviation of $y$-intercepts of regression lines, and $S$ is the slope of the calibration curve.

2.7.5. Robustness. Robustness of the method was studied by deliberately changing the experimental conditions like flow rate, percentage of organic phase, $\mathrm{pH}$ of mobile phase, and also by observing the stability of the sample solution at $25 \pm 2^{\circ}$ $\mathrm{C}$ for $24 \mathrm{~h}$. The sample solution was assayed at every 2-hour interval up to $24 \mathrm{~h}$.

2.8. Forced Degradation Study. Stress degradation study using acid and alkali hydrolysis, chemical oxidation, and dry heat degradation was carried out, and interference of the degradation products was investigated. ILO was weighed $(10 \mathrm{mg})$ and transferred to $10 \mathrm{~mL}$ volumetric flasks and diluted up to the mark with mobile phase. These stock solutions were used for forced degradation studies.

(a) Alkali Hydrolysis. To the $10 \mathrm{~mL}$ volumetric flask, $10 \mathrm{mg}$ of ILO was taken and $2 \mathrm{~mL}$ of $1 \mathrm{~N} \mathrm{NaOH}$ was added to perform base hydrolysis. The flask was heated at $80^{\circ} \mathrm{C}$ for 1 week and allowed to cool to room temperature. Solution was neutralized with $1 \mathrm{~N} \mathrm{HCl}$ and diluted up to the mark with mobile phase. Appropriate aliquots was taken from the above solution and diluted with mobile phase to obtain final concentration of $10 \mu \mathrm{g} \mathrm{mL}^{-1}$ of ILO. (b) Acid Hydrolysis. To the $10 \mathrm{~mL}$ volumetric flask, $10 \mathrm{mg}$ of ILO was taken and $2 \mathrm{~mL}$ of $1 \mathrm{~N} \mathrm{HCl}$ was added to perform acid hydrolysis. The flask was heated at $80^{\circ} \mathrm{C}$ for 1 week and allowed to cool to room temperature. Solution was neutralized with $1 \mathrm{~N} \mathrm{NaOH}$ and diluted up to the mark with mobile phase. Appropriate aliquot was taken from the above solution and diluted with mobile phase to obtain final concentration of $10 \mu \mathrm{g} \mathrm{mL}-1$ of ILO.

(c) Oxidative Stress Degradation. To perform oxidative stress degradation, $10 \mathrm{mg}$ of ILO was taken in $10 \mathrm{~mL}$ volumetric flask and $2 \mathrm{~mL}$ of $3 \%$ hydrogen peroxide was added. The mixture was heated in a water bath at $80^{\circ} \mathrm{C}$ for $2 \mathrm{~h}$ and allowed to cool to room temperature and diluted up to the mark with mobile phase. Appropriate aliquot was taken from above solution and diluted with mobile phase to obtain final concentration of $10 \mu \mathrm{g} \mathrm{mL}^{-1}$ of ILO.

(d) Dry Heat Degradation. Analytically pure sample of ILO was exposed in oven at $80^{\circ} \mathrm{C}$ for 1 week. The solids were allowed to cool, and $10 \mathrm{mg}$ of ILO was weighed, transferred to volumetric flasks $(10 \mathrm{~mL})$, and dissolved in few $\mathrm{mL}$ of acetonitrile. Volume was made up to the mark with the acetonitrile. Solution was further diluted by mobile phase taking appropriate aliquots in $10 \mathrm{~mL}$ volumetric flask to obtain final concentration of $10 \mu \mathrm{g} \mathrm{mL}-1$ of ILO.

(e) To study photolytic (sunlight) degradation, solid drugs were exposed to sunlight for 1 week. After exposure, $10 \mathrm{mg}$ of ILO was weighed and transferred to volumetric flask $(10 \mathrm{~mL})$ and dissolved in few $\mathrm{mL}$ of acetonitrile. Volume was made up to the mark with the acetonitrile. Solution was further diluted with the mobile phase taking appropriate aliquots in $10 \mathrm{~mL}$ volumetric flask to obtain final concentration of $10 \mu \mathrm{g} \mathrm{mL} \mathrm{m}^{-1}$ of ILO.

All the reaction solutions were injected in the liquid chromatographic system, and chromatograms were recorded. 


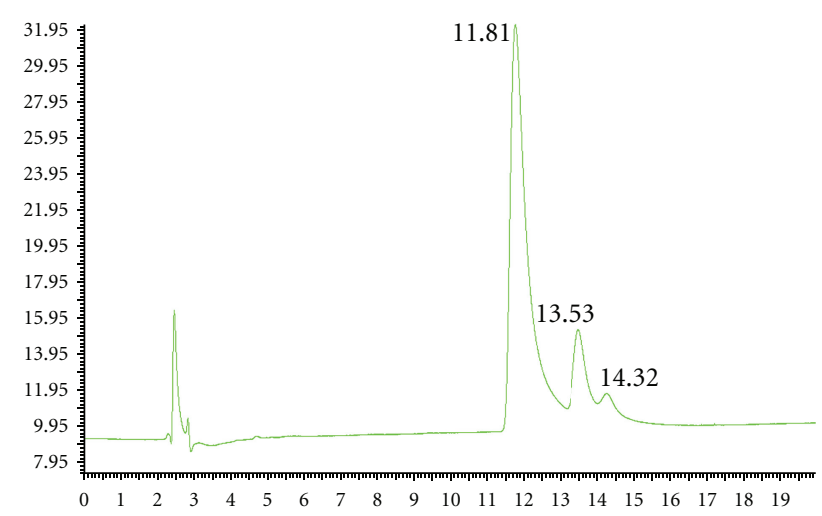

Figure 3: Chromatogram of $3 \% \mathrm{H}_{2} \mathrm{O}_{2}$-treated ILO at $80^{\circ} \mathrm{C}$ temperature for $2 \mathrm{hr}$ reflux.

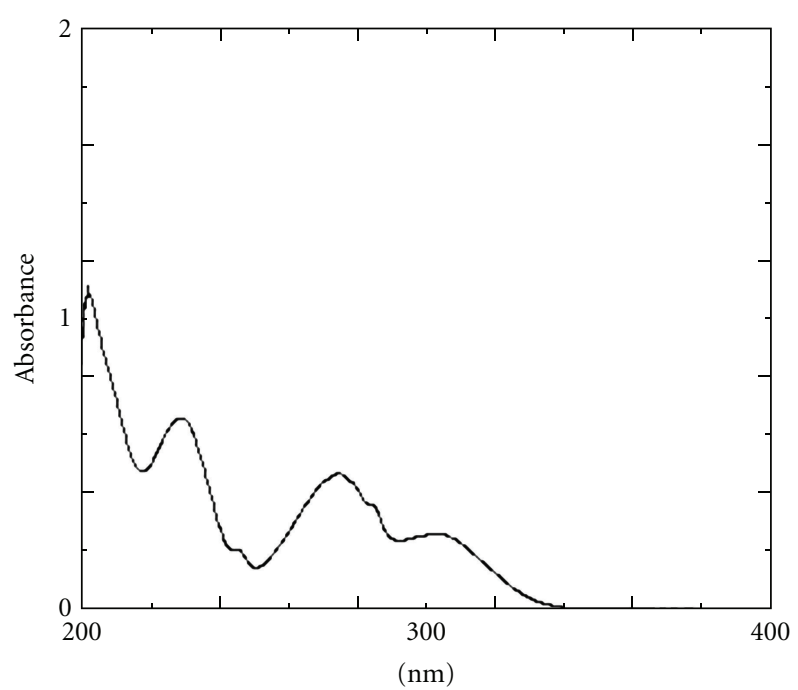

FIgURE 4: UV spectra of ILO $(10 \mu \mathrm{g} / \mathrm{mL})$ in mobile phase.

\section{Results and Discussion}

3.1. Optimization of Mobile Phase. Optimization of mobile phase was performed based on resolution of the drug, and degradation products, asymmetric factor, and theoretical plates were obtained for ILO. The mobile phase consists of $0.02 \mathrm{M}$ potassium dihydrogen. Phosphate: methanol: acetonitrile (55:25:20, v/v/v, pH 4 adjusted with phosphoric acid) was selected which gave sharp, well-resolved peak for ILO (Figure 2). Degradation was observed in oxidative stress condition (Figure 3).

The retention time for ILO was $11.6 \mathrm{~min}$. The asymmetric factor for ILO was 1.06. UV spectra of ILO showed (Figure 4) that the drug was absorbed appreciably at $230 \mathrm{~nm}$, so the same was selected as the detection wavelength during the studies.

3.2. Validation. The calibration curve was found to be linear over the range of $0.1-20 \mu \mathrm{g} / \mathrm{mL}$ for ILO. The data of regression analysis of the calibration curves are shown in Table 1.
TABLE 1: Regression analysis of the calibration curve and summary of validation parameters.

\begin{tabular}{lc}
\hline Parameters & ILO \\
\hline Linearity range $(\mu \mathrm{g} / \mathrm{mL})$ & $0.1-20$ \\
Slope & 60966 \\
Standard deviation of slope $(\mathrm{SD})$ & 320.69 \\
Intercept & 2697.64 \\
Standard deviation of intercept $(\mathrm{SD})$ & 405.28 \\
Correlation coefficient & 0.9996 \\
Detection limit $(\mu \mathrm{g} / \mathrm{mL})$ & 0.022 \\
Quantitation limit $(\mu \mathrm{g} / \mathrm{mL})$ & 0.067 \\
Accuracy $(\%)$ & $99.26-100.33$ \\
Precision $(\mathrm{RSDa}, \%)$ & \\
Intraday precision $(n=3)$ & $0.33-1.06$ \\
Interday precision $(n=3)$ & $0.41-1.14$ \\
Repeatability study $(\mathrm{RSDa}, \%)$ & 0.49 \\
\hline${ }^{a} \mathrm{RSD}$ is relative standard deviation and, " $n$ " is the number of determina- \\
tions.
\end{tabular}

TABLe 2: System suitability test parameters for the proposed method.

\begin{tabular}{lc}
\hline System suitability parameters & ILO \\
\hline Retention time (min) & 11.6 \\
Theoretical plates/meter & 5353.92 \\
Asymmetric factor & 1.06 \\
\hline
\end{tabular}

The accuracy of the method was determined by calculating recoveries of ILO by the method of standard additions. The recoveries for ILO obtained were 99.25-100.33\%. The high values indicate that the method is accurate. Repeatability study was performed, and RSD value for ILO was found to be $0.49 \%$. The intraday and interday precision studies were carried out. For the intraday and interday precision study, RSD values were found to be $0.33-1.06 \%$ and $0.40-$ $1.14 \%$ for ILO, respectively. The low RSD values indicate that the method is precise. The detection limit for ILO was $0.022 \mu \mathrm{g} / \mathrm{mL}$, while quantitation limit was $0.067 \mu \mathrm{g} / \mathrm{mL}$, respectively. The above data shows that a nanogram quantity of the drug can be accurately and precisely determined. The validation parameters are summarized in Table 1, and the system suitability test parameters are shown in Table 2.

Robustness of the method was studied by changing the flow rate of the mobile phase from $1 \mathrm{~mL} / \mathrm{min}$ to $0.9 \mathrm{~mL} / \mathrm{min}$ and $1.1 \mathrm{~mL} / \mathrm{min}$. Using $1.1 \mathrm{~mL} / \mathrm{min}$ flow rate, retention time for ILO was observed to be 11.00 and with $0.9 \mathrm{~mL} / \mathrm{min}$ flow rate, retention time for ILO was observed to be 12.1, respectively, without affecting the resolution of the drugs. When mobile-phase composition was changed to $0.02 \mathrm{M}$ potassium dihydrogen phosphate:methanol:acetonitrile (50:25:25, $\mathrm{v} / \mathrm{v} / \mathrm{v}, \mathrm{pH} 4$ adjusted with phosphoric acid) by increasing percentage of acetonitrile, the retention time of ILO was observed to be 11.1, while mobile-phase composition was changed to $0.02 \mathrm{M}$ potassium dihydrogen phosphate: methanol:acetonitrile $(60: 25: 15, \mathrm{v} / \mathrm{v} / \mathrm{v}, \mathrm{pH} 4$ adjusted with phosphoric acid) by decreasing percentage of 
TABLe 3: Data derived from robustness for proposed method.

\begin{tabular}{lccc}
\hline Parameters & $\begin{array}{c}\text { Normal } \\
\text { condition }\end{array}$ & $\begin{array}{c}\text { Change in } \\
\text { condition }\end{array}$ & $\begin{array}{c}\text { Change in \% } \\
\text { RSD }\end{array}$ \\
\hline Flow rate & $1.0 \mathrm{~mL} / \mathrm{min}$ & $0.9 \mathrm{~mL} / \mathrm{min}$ & 0.94 \\
& & $1.1 \mathrm{~mL} / \mathrm{min}$ & 1.01 \\
$\mathrm{Ph}$ & \multirow{2}{*}{4.0} & 3.5 & 1.06 \\
& & 4.5 & 0.56 \\
Mobile phase & $55: 25: 20$ & $50: 25: 25$ & 0.77 \\
ratio & & $60: 25: 15$ & 1.02 \\
\hline
\end{tabular}

TABle 4: Data derived from forced degradation study for the proposed HPLC method.

\begin{tabular}{lccc}
\hline Condition & Time (h) & $\begin{array}{c}\text { \% Recovery } \\
\text { ILO }\end{array}$ & $\begin{array}{c}\text { Retention } \\
\text { time of } \\
\text { degradation } \\
\text { products }\end{array}$ \\
\hline $\begin{array}{l}\text { Base } 1 \mathrm{~N} \\
\mathrm{NaOH}\end{array}$ & 1 week & 100.4 & - \\
$\begin{array}{l}\text { Acid } 1 \mathrm{~N} \mathrm{HCl} \\
3 \% \text { hydrogen } \\
\text { peroxide }\end{array}$ & 1 week & 99.1 & - \\
$\begin{array}{l}\text { Dry heat } \\
\text { bunlight }\end{array}$ & 1 week & 81.7 & $13.53,14.32$ \\
\hline${ }^{\mathrm{b}}$ Samples were heated at $80^{\circ} \mathrm{C}$ for a specified period of time. &
\end{tabular}

${ }^{\mathrm{b}}$ Samples were heated at $80^{\circ} \mathrm{C}$ for a specified period of time.

TABLe 5: Assay results of tablet dosage form using proposed method.

\begin{tabular}{lccc}
\hline Tablet & $\begin{array}{c}\text { Labelled } \\
\text { amount }(\mathrm{mg})\end{array}$ & $\begin{array}{c}\text { Amount } \\
\text { recovered } \\
(\mu \mathrm{g} / \mathrm{mL})\end{array}$ & \% recovery \\
\hline A & 4 & 3.97 & $\begin{array}{c}99.33 \pm \\
0.5204\end{array}$ \\
\hline
\end{tabular}

${ }^{c}$ Mean value \pm standard deviation of three determinations; tablet formulation A is ILOSURE (Sun Pharmaceutical Industries Ltd, Baroda, Gujarat, India) containing labeled amount of $4 \mathrm{mg}$ of iloperidone.

acetonitrile, the retention time of ILO was observed to be 12.0 , respectively. When $\mathrm{pH}$ of mobile phase was changed from 4.0 to 3.5 and 4.5 at this $\mathrm{pH}$, there was not seen any kind of change on the retention time. The robustness parameters are shown in Table 3 . The solution stability study revealed that ILO solution was stable for $24 \mathrm{~h}$ without detectable degradation, and the percentage recovery of both the drugs was found to be more than $98 \%$.

3.3. Forced Degradation Study. Forced degradation study was carried out by subjecting the drug to acid and alkali hydrolysis, chemical oxidation, and dry heat degradation conditions. The ILO was found to be stable to acid and alkali hydrolysis, dry heat degradation, and photolytic (sunlight) condition. Degradation was observed in oxidative stress condition (Table 4).

3.4. Analysis of Marketed Formulation. The proposed method was applied to the determination of ILO in their pharmaceutical dosage form (Tablet A). The result for ILO was comparable with the corresponding labeled amounts (Table 5). The chromatogram of marketed formulation analysis is shown in Figure 4.

\section{Conclusion}

A validated stability-indicating RP-HPLC analytical method has been developed for the estimation of iloperidone in bulk and in their pharmaceutical dosage form. Compared to reported method [6], the proposed method is sensitive, and it is developed with a simple mobile phase. The results of stress testing undertaken according to the ICH guidelines revealed that the method is selective and stabilityindicating. Apart from oxidative stress condition, the drug was found to be stable in rest of forced degradation condition. The proposed method was validated and found to be simple, accurate, precise, and specific. The method was successfully applied for the estimation of tablet dosage form. The proposed liquid chromatographic method can be applied to the analysis of samples obtained during accelerated stability experiments to predict expiration dates of pharmaceuticals.

\section{Acknowledgments}

The authors are grateful to Sun Pharmaceutical Pvt. Ltd., Baroda, India for providing a gift sample of iloperidone. The authors are also very thankful to SICART and Indukaka Ipcowala College of Pharmacy, New Vallabh Vidyanagar, for providing necessary facilities to carry out research work.

\section{References}

[1] Fanapt (Iloperidone) Tablets, Highlights of Prescribing Information (Revised 05/2009) and Full Prescribing Information, Vanda Pharmaceuticals Inc., Rockville, Md, USA, 2009.

[2] J. P. Kelleher, F. Centorrino, M. J. Albert, and R. J. Baldessarini, "Advances in atypical antipsychotics for the treatment of schizophrenia: new formulations and new agents," CNS Drugs, vol. 16, no. 4, pp. 249-261, 2002.

[3] A. E. Mutlib and J. T. Strupczewski, "Picogram determination of iloperidone in human plasma by solid-phase extraction and by high-performance liquid chromatography-selectedion monitoring electrospray mass spectrometry," Journal of Chromatography B, vol. 669, no. 2, pp. 237-246, 1995.

[4] S. M. Sainati, J. W. Hubbard, E. Chi, K. Grasing, and M. B. Brecher, "Safety, tolerability, and effect of food on the pharmacokinetics of iloperidone (HP 873), a potential atypical antipsychotic," Journal of Clinical Pharmacology, vol. 35, no. 7, pp. 713-720, 1995.

[5] A. E. Mutlib, J. T. Strupczewski, and S. M. Chesson, "Application of hyphenated LC/NMR and LC/MS techniques in rapid identification of in vitro and in vivo metabolites of iloperidone," Drug Metabolism and Disposition, vol. 23, no. 9, pp. 951-964, 1995.

[6] L. P. Mandpe and V. B. Pokharkar, "Stress degradation studies on Iloperidone and development of a stability indicating HPLC method for bulk drug and pharmaceutical dosage form," Chimica Sinica, vol. 2, no. 2, pp. 230-239, 2011. 
[7] International Conference on Harmonization, Q1B Photo stability Testing of New Drug Substances and Products International Conference on Harmonization, IFPMA, Geneva, Switzerland, 1996.

[8] International Conference on Harmonization, Q2 (R1) Validation of Analytical Procedure, Test and Methodology, International Conference on Harmonization, International Conference on Harmonization, Geneva, Switzerland, 2005.

[9] International Conference on Harmonization, Q2A Validation of Analytical Procedures: Consensus Guidelines, ICH Harmonized Tripartite Guidelines, 1994.

[10] International Conference on Harmonization, Q2B Validation of Analytical Procedures: Methodology, Consensus Guidelines, ICH Harmonized Tripartite Guidelines, 1996.

[11] International Conference on Harmonization, Q1A (R2) Stability Testing of New Drug Substances and Products International Conference on Harmonization, IFPMA, Geneva, Switzerland, 2003. 


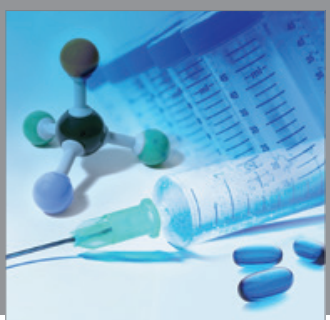

International Journal of

Medicinal Chemistry

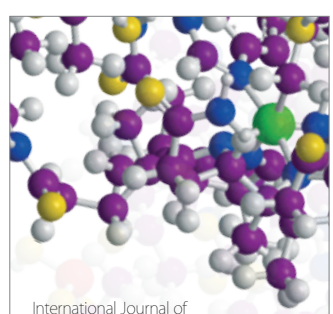

Carbohydrate Chemistry

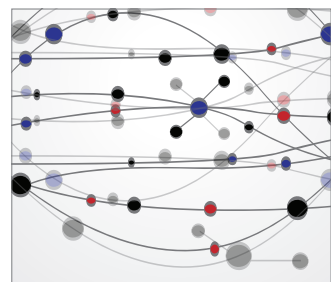

The Scientific World Journal
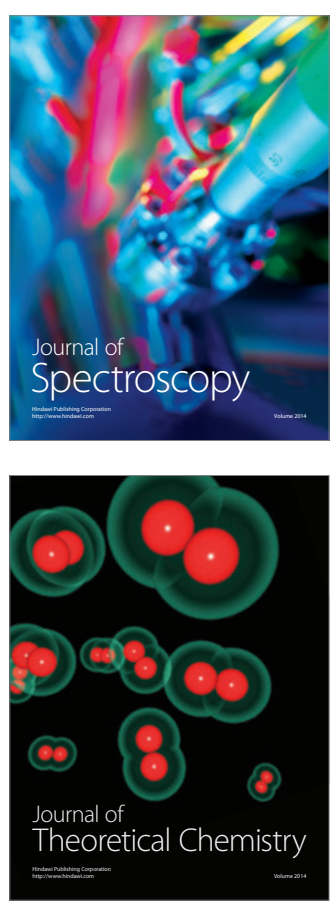
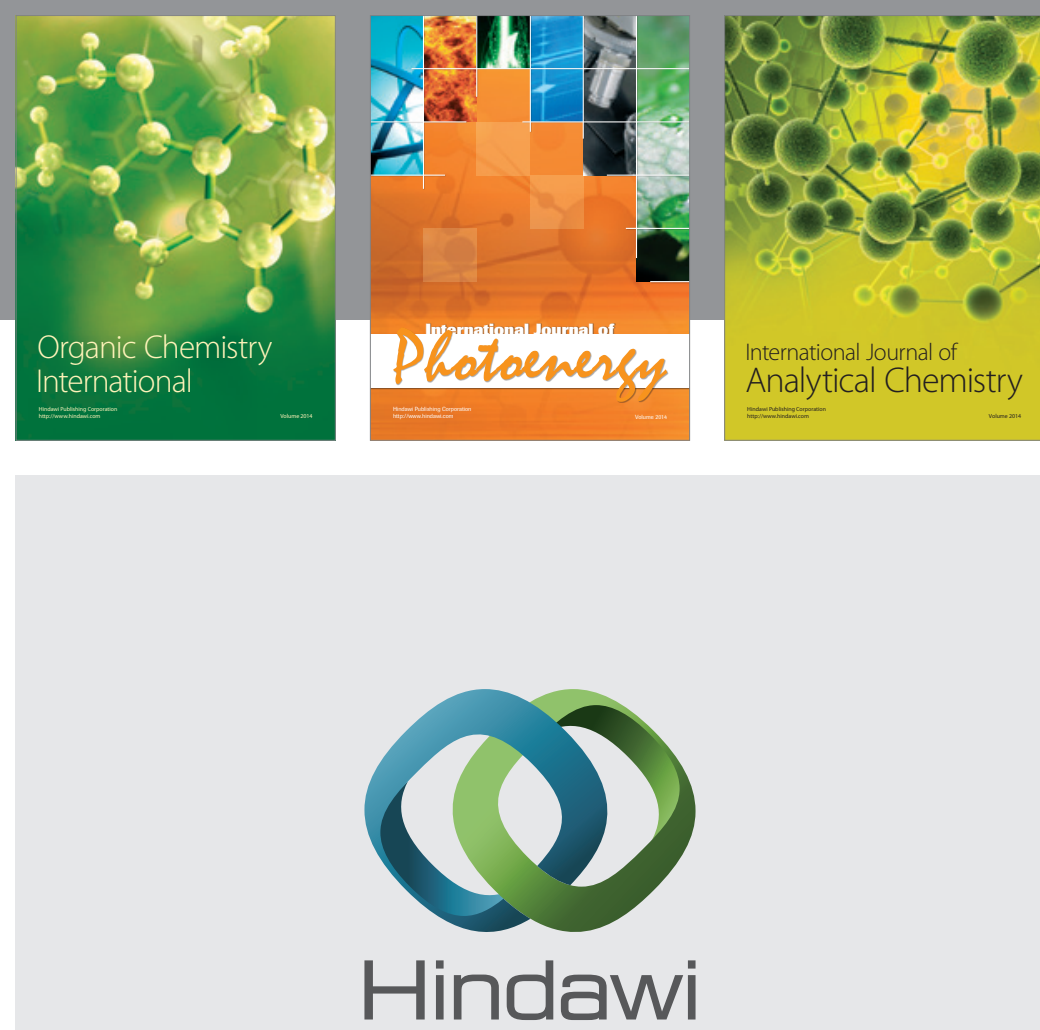

Submit your manuscripts at

http://www.hindawi.com
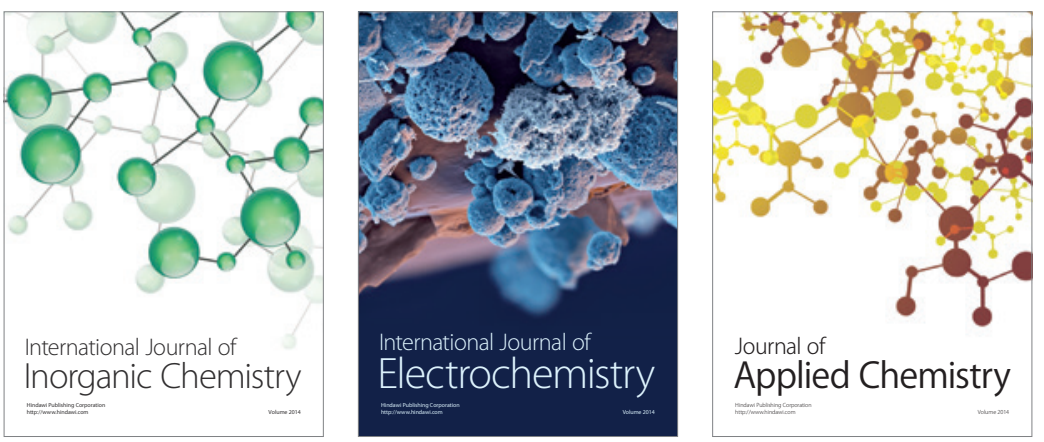

Journal of

Applied Chemistry
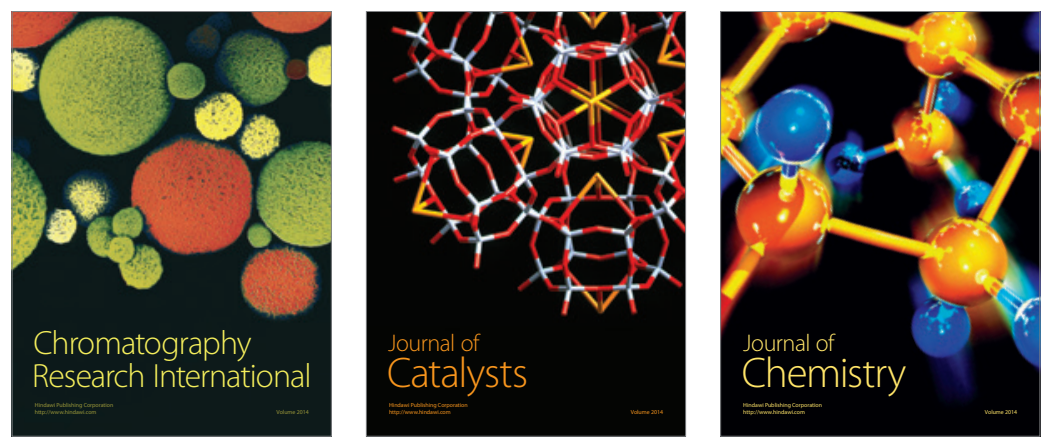
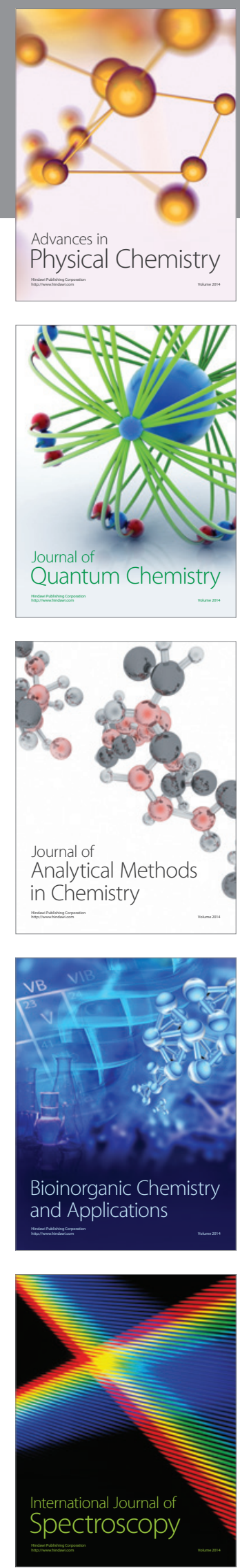